\title{
Pengaruh Corporate Governance terhadap Earnings Management Perusahaan IPO
}

\author{
Endang Satriani Siregar \\ Magister Ilmu Manajemen, Universitas Sumatera Utara \\ satrianiendangbr.regar@gmail.com
}

\begin{abstract}
Abstrak
Penelitian ini mengkaji pengaruh corporate governance terhadap earnings management perusahaan yang melakukan IPO. Tujuan perusahaan adalah meningkatkan dana yang dapat diperoleh pada saat IPO tanpa disadari public. Perusahaan perlu meningkatkan daya tarik saham perusahaan melalui laporan keuangan, karena laporan keuangan merupakan landasan para investor sebelum melakukan investasi. Beberapa penelitian menunjukkan bahwa perusahaan yang melakukan IPO memiliki discretionary accrued income lebih tinggi dibanding dengan perusahaan yang belum melakukan IPO. Perusahaan yang melakukan IPO memiliki hak akrual yang lebih tinggi, dan kinerjanya akan menurun dalam tiga tahun setelah IPO. Namun hasil penelitian ini tidak menemukan bukti bahwa penurunan kinerja disebabkan oleh earnings management pada saat IPO. Hasil penelitian ini juga menunjukkan jika hanya dewan komisaris dapat menurunkan earnings management.
\end{abstract}

Kata Kunci: Earnings Management; IPO; Corporate Governance

\section{PENDAHULUAN}

Dewasa ini, investasi saham merupakan kegiatan yang banyak dilakukan masyarakat dalam menginvestasikan uangnya. Tentunya dalam melakukan investasi saham banyak pertimbangan-pertimbangan yang dilakukan investestor, salah satunya apakah perusahaan tersebut sudah melakukan IPO atau belum. Banyak penelitian yang meneliti kecenderungan earnings management pada perusahaan yang melakukan penawaran saham pertamanya, atau yang dikenal dengan Initial Public Offering (IPO). Manajemen perusahaan memiliki kesempatan 
untuk melakukan tindakan oportunis pada saat melakukan IPO, seperti meningkatkan laba (Chen et al., 2005; Ducharme et al., 2001).

Tindakan oportunis tersebut dapat menguntungkan manajemen perusahaan karena akan mendapatkan pendanaan yang besar. namun, pemegang saham yang akan menanggung resikonya. Permasalahan ini sesuai dengan agency theory. Tindakan oportunis dapat dilakukan manajemen karena manajemen tersebutlah yang memiliki wewenang terhadap operasional perusahaan. Manajemen perusahaan (agent) melakukan earnings management untuk meningkatkan laba perusahaan untuk memperoleh pendanaan dari investor yang lebih besar dari semestinya (Sulistiawan et al., 2011). Meningkatkan laba perusahaan juga dapat membuat manajemen mendapatkan remunerasi yang lebih banyak dari seharusnya (Hand dan Skantz, 1998, dan Shuto, 2007, dalam Iatridis dan Kadorinis, 2009).

Ducharme et al. (2001) melakukan penelitian terhadap seluruh perusahaan yang melakukan IPO dari tahun 1982 dan 1987 yang tersedia di Investment Dealers' Digest Information Services. Hasil dari penelitiannya adalah perusahaan yang menerbitkan saham perdananya secara oportunis memanipulasi labanya untuk meningkatkan proses IPO. Hal tersebut akan membuat investor tertipu untuk sementara dan menyebabkan harapan yang terlalu optimis tentang prospek perusahaan.

Teoh et al. (1998) juga meneliti perusahaan yang melakukan IPO. Sampel yang digunakan adalah 1.974 perusahaan yang melakukan IPO di Amerika dari tahun 1980 hingga 1992. Hasilnya menyatakan bahwa perusahaan yang melakukan IPO, memiliki discretionary accrual yang tinggi di sekitaran periode IPO. Yang berarti bahwa perusahaan IPO melakukan earnings management, yang terlihat dari discretionary accrual-nya yang tinggi.

Berdasarkan penelitian terdahulu, baik yang meneliti pengaruh earnings management dengan perusahaan yang melakukan IPO dan pengaruh corporate governance terhadap earnings management, menunjukkan hasil yang sama. Penelitian ini ingin melihat keberadaan tindakan manajemen laba yang dilakukan oleh perusahaan yang melakukan IPO di Indonesia. Penelitian ini juga akan melihat dampak manajemen laba terhadap kinerja perusahaan yang melakukan IPO hingga beberapa tahun setelahnya, baik dari sisi keuangan perusahaan, maupun pasar.

\section{LANDASAN TEORI}

\section{Earnings Management}

Cara yang akan digunakan untuk menghitung Earnings Management dalam penelitian ini adalah Modified Jones Model (Dechow et al., 1995). Cara tersebut dipilih karena model tersebut merupakan model yang paling kuat untuk mendeteksi earnings management dibandingkan model lainnya untuk mengukur akrual yang tidak terduga, model ini juga memperhitungkan piutang, sehingga akan mengurangi kemungkinan manipulasi penjualan kredit (Dechow et al., 1995). Ahmad-Zaluki (2011) menggunakan Modified Jones Model dalam penelitiannya, dan menyatakan bahwa nilai positif discretionary accrual memiliki arti bahwa perusahaan melakukan manajemen laba income 9 increasing. 
Earnings management akan diukur sesuai dengan cara yang dilakukan oleh Ahmad-Zaluki (2011), yaitu:

$$
\begin{aligned}
& T A C C_{i t}=\mathrm{NI}_{i t}+O C F_{i t} \\
& T A C C_{i t}=\alpha_{1} \frac{1}{T A_{i t-1}}+\alpha_{2} \frac{\left(R E V_{i t}-R E V_{i t-1}\right)}{T A_{i t-1}}+\alpha_{3} \frac{P P E_{i t}}{T A_{i t-1}}+\varepsilon_{i t} \\
& N D A C_{i t}=\alpha_{1} \frac{1}{T A_{i t-1}}+\alpha_{2} \frac{\left(R E V_{i t}-R E V_{i t-1}\right)-\left(R E C_{i t}-R E C_{i t-1}\right)}{T A_{i t-1}}+\alpha_{3} \frac{P P E_{i t}}{T A_{i t-1}}+\varepsilon_{i t} \\
& D_{A C C}=\mathrm{TACC}_{i t}-N D A C_{i t}
\end{aligned}
$$

Keterangan;

TACCit $=$ total akrual perusahaan i pada tahun $\mathrm{t}$

NIit = laba bersih perusahaan $\mathrm{i}$ pada tahun $\mathrm{t}$

OCFit = arus kas dari aktivitas operasi perusahaan i pada tahun $\mathrm{t}$

TAit- $1=$ total aset perusahaan i pada tahun sebelumnya

$\mathrm{REVit}=$ total pendapatan operasional perusahaan i pada tahun $\mathrm{t}$

REVit-1 = total pendapatan operasional perusahaan i pada tahun sebelumnya

PPEit $=$ total aset tetap kotor perusahaan $\mathrm{i}$ pada tahun $\mathrm{t}$

NDACit $=$ nondiscretionary accrual perusahaan i pada tahun $\mathrm{t}$

RECit $=$ total piutang usaha perusahaan i pada tahun $t$

RECit-1 = total piutang usaha perusahaan i pada tahun sebelumnya

DACCit $=$ discretionary accrual perusahaan i pada tahun $\mathrm{t}$

Eit $=$ error term perusahaan $\mathrm{i}$ pada tahun $\mathrm{t}$

\section{Return on Assets}

ROA akan dihitung dengan menggunakan rumus;

$$
R O A i, t=\frac{\text { Laba Tahun Berjalan }}{\text { Total Aset }}
$$

\section{Buy-and-Hold Abnormal Return (BHAR)}

BHAR akan dihitung dengan menggunakan rumus;

Persamaan 6: menghitung return saham perusahaan $i$ pada periode $t$.

$$
\mathrm{R}_{\mathrm{it}}=\prod\left(1+\mathrm{r}_{\mathrm{it}}\right)-1
$$

Persamaan 7: menghitung expected return (benchmark) pada periode $t$.

$$
\mathrm{R}_{\mathrm{bt}}=\prod\left(1++_{\mathrm{rt}}\right)-1
$$

Persamaan 8: selisih antara return tiap perusahaan dengan expected return pada periode $t$, akan menjadi Buy-and-Hold Abnormal Return (BHAR).

$$
\text { BHAR }_{\text {it }}=\mathrm{R}_{\mathrm{it}}-\mathrm{R}_{\mathrm{bt}}
$$

Keterangan;

Rit $=$ Return perusahaan i pada periode $\mathrm{t}$.

rit $=$ Return harian perusahaan i pada periode $\mathrm{t}$.

$\mathrm{Rbt}=$ Return indeks pasar pada periode $\mathrm{t}$. 
rbt $=$ Return harian indeks pasar pada perioed $\mathrm{t}$.

BHARit $=$ Buy-and-Hold Abnormal Return perusahaan i pada periode $\mathrm{t}$.

\section{METODE PENELITIAN}

Obyek penelitian ini adalah badan usaha yang bergerak di berbagai sektor kecuali sektor keuangan dan melakukan IPO dan yang tidak melakukan IPO yang terdaftar di Bursa Efek Indonesia (BEI) pada tahun 2013 - 2016. Kinerja perusahaan akan diamati hingga maksimal $t+3$

\section{Descriptive Statistics}

Berdasarkan Panel A, dapat dilihat bahwa DACC perusahaan yang melakukan IPO secara rata-rata pada periode $\mathrm{t}(0,081)$ lebih tinggi dibandingkan DACC perusahaan yan tidak melakukan IPO $(0,04)$. Hal tersebut menyatakan bahwa perusahaan yang melakukan IPO cenderung melakukan manajemen laba untuk meningkatkan labanya pada periode IPO-nya. Manajemen laba perusahaan IPO juga terlihat menurun pada periode setelah IPO. Rata-rata variabel corporate governance perusahaan IPO ada yang lebih baik dari perusahaan yang tidak melakukan IPO, yaitu IND (0,416 dan 0,4), MEET (5,92 dan 5,88), dan MO (0,036 dan 0,006). Namun lebih banyak variabel corporate governance perusahaan IPO yang memiliki rata-rata lebih rendah dibandingkan perusahaan Non-IPO, yaitu SOB $(3,7$ dan 4,86), AC (3 dan 3,08), ACE $(0,653$ dan 0,667), dan ADR $(0,12$ dan $0,48)$.

Berdasarkan Panel B, perusahaan yang melakukan IPO memiliki rata-rata ROA yang hampir sama dengan perusahaan yang tidak melakukan IPO. Perusahaan yang melakukan IPO memiliki rata-rata ROA sebesar 0,0709 dan rata-rata ROA perusahaan yang tidak melakukan IPO 0,0781. Perusahaan yang melakukan IPO menunjukkan kinerja return saham yang lebih baik pada periode $t$ dibandingkan dengan perusahaan yang tidak melakukan IPO yang terlihat dari nilai BHAR $(0,0909$ dan 0,0309$)$. Pada periode $t+1$ hingga $t+3$, baik perusahaan yang melakukan IPO maupun tidak, sama-sama memiliki nilai BHAR yang negatif. Penurunan yang paling signifikan terjadi pada periode $t+1$ perusahaan yang melakukan IPO.

DACC perusahaan IPO maupun Non-IPO, terlihat tidak banyak berubah karena nilai DACC yang digunakan pada periode $t+1$ hingga $t+3$ adalah nilai DACC pada periode $t$. Hal tersebut digunakan untuk melihat pengaruhnya manajemen laba yang dilakukan pada periode $t$ terhadap kinerja baik dari internal maupun eksternal pada periode selanjutnya.

\section{Regresi Linier}

Panel A menunjukkan hasil pengujian regresi linier model regresi 9-12 pada perusahaan yang melakukan IPO. Hasil regresi linier menunjukkan perubahan yang tidak searah pada SOB dengan manajemen laba pada periode $t$ dan $t+2$. Perubahan searah ditunjukkan variabel MEET dan ACE dengan manajemen laba pada periode $\mathrm{t}+3$. Dan panel B menunjukkan hasil pengujian regresi linier model regresi 9-12 pada perusahaan yang tidak melakukan IPO. Berdasarkan hasil pengujian, hubungan searah ditunjukkan variabel ACE pada periode $t+1$. Hubungan tidak searah ditunjukkan oleh variabel SOB dan LEV pada periode $t+1$. 
Panel C menunjukkan hasil pengujian regresi linier model regresi 13 dan 14 perusahaan yang melakukan IPO dan tidak. Berdasarkan hasil pengujian, tidak ada variabel yang mempengaruhi secara signifikan kinerja perusahaan baik pengukuran secara internal maupun eksternal. Dan panel D menunjukkan hasil pengujian regresi linier model regresi 15-17 perusahaan yang melakukan IPO. Berdasarkan hasil pengujian, hubungan searah ditunjukkan variabel LTA dengan ROA pada periode $t+1$ hingga $t+3$. Hubungan tidak searah ditunjukkan variabel LEV dengan ROA pada periode $t+1$. Dan panel $E$ menunjukkan hasil pengujian regresi linier model regresi 15-17 perusahaan yang tidak melakukan IPO. Hasil pengujian menunjukkan LEV memiliki hubungan yang tidak searah dengan ROA pada periode $t+1$ dan $t+3$.

Panel $\mathrm{F}$ menunjukkan hasil pengujian regresi linier model regresi 18-20 perusahaan yang melakukan IPO. Hasil pengujian menunjukkan LTA memiliki hubungan searah dengan BHAR pada periode $t+2$. Dan panel $G$ menunjukkan hasil pengujian regresi linier model regresi 18-20 perusahaan yang tidak melakukan IPO. Hasil pengujian menunjukkan tidak ada variabel yang mempengaruhi BHAR secara signifikan dari periode $t+1$ hingga $t+3$.

\section{HASIL DAN PEMBAHASAN}

Berdasarkan hasil penelitian ini, terbukti bahwa perusahaan yang melakukan IPO di Indonesia melakukan earnings management. Perbedaan yang cukup jauh terlihat pada rata-rata discretionary accrual antara perusahaan yang melakukan IPO dan yang tidak. Earnings management yang tinggi saat IPO sesuai dengan teori motivasi earnings management yang dikemukakan Scott (2015), dan Jones (2011).

Hasil penelitian menunjukkan jika corporate governance terbukti tidak memiliki pengaruh yang besar terhadap manajemen laba. Perusahaan yang melakukan IPO terbukti melakukan manajemen laba untuk meningkatkan labanya pada periode IPO, dibuktikan melalui rata-rata statistik deskriptifnya yang lebih tinggi dibandingkan nilai rata-rata 19 manajemen laba pada perusahaan yang tidak melakukan IPO. Hanya size of board yang memiliki pengaruh negatif yang signifikan terhadap manajemen pada periode $t$ perusahaan IPO. Hal tersebut menunjukkan jumlah anggota dewan komisaris dapat menurunkan manajemen laba pada periode perusahaan melakukan IPO. Size of board juga menurunkan manajemen laba pada periode $\mathrm{t}+2$ perusahaan IPO dan $\mathrm{t}+1$ perusahaan Non-IPO. Hal tersebut menunjukkan jumlah dewan komisaris terkadang memiliki pengaruh yang cukup kuat untuk menurunkan manajemen laba. Manajemen laba perusahaan IPO pada periode $t+3$ dipengaruhi secara positif oleh jumlah rapat dewan komisaris dan latar belakang pendidikan atau pengalaman anggota komite audit. Komite audit juga berpengaruh positif terhadap manajemen laba pada periode $t+1$ perusahaan Non-IPO.

Hasil penelitian ini tidak membuktikan manajemen laba berpengaruh terhadap Return on Assets dan Buy-andHold Abnormal Return baik perusahaan yang melakukan IPO ataupun tidak. Walaupun perusahaan IPO memiliki nilai manajemen laba yang lebih tinggi dibandingkan perusahaan yang tidak melakukan IPO, tapi penelitian ini tidak menemukan pengaruhnya terhadap ROA dan BHAR. Berdasarkan hasil regresi linier, penelitian ini tidak membuktikan manajemen laba yang dilakukan pada periode $t$ memiliki pengaruh terhadap kinerja perusahaan pada periode setelahnya.

Jurnal Insitusi Politeknik Ganesha Medan

Juripol, Volume 4 Nomor 1 Maret 2021 


\section{KESIMPULAN}

Berdasarkan hasil penelitian diatas, dapat disimpulkan jika corporate governance terbukti tidak memiliki pengaruh yang besar terhadap manajemen laba. Perusahaan yang melakukan IPO terbukti melakukan manajemen laba untuk meningkatkan labanya pada periode IPO. Manajemen laba tidak berpengaruh terhadap Return on Assets dan Buy-and Hold Abnormal Return baik perusahaan yang melakukan IPO ataupun tidak. Walaupun perusahaan IPO memiliki nilai manajemen laba yang lebih tinggi dibandingkan perusahaan yang tidak melakukan IPO. Hasil penelitian ini juga tidak menemukan pengaruhnya terhadap ROA dan BHAR. Serta secara linier hasil penelitian tidak menunjukan jika manajemen laba yang dilakukan pada periode $t$ memiliki pengaruh terhadap kinerja perusahaan pada periode setelahnya.

\section{REFERENSI}

Abaddi, S. S., Hijazi, Q. F., dan Al-Rahahleh, A. S. 2016. Corporate Governance Quality and Earnings Management: Evidence from Jordan. Australasian Accounting, Business and Finance Journal, Vol. 10 (2): 55-75.

Ahmad-Zaluki, N. A. 2008. Post-IPO operating performance and earnings management. International Business Research, Vol. 1 (2): 39-48.

Alves, S. 2012. Ownership structure and earnings management: evidence from Portugal. Australasian Accounting Business and Finance, Vol. 6(1): 57-74.

Alzoubi, E. S. 2016. Ownership structure and earnings management: evidence from Jordan. International Journal of Accounting \& Information Management, Vol. 24 (2): 135-161.

Bedard, J., Chtourou, S. M., dan Corteau, L. 2004. The effect of audit committee expertise, independence, and activity on aggresive earnings management. Auditing: A Journal of Practice \& Theory, Vol. 23 (2): 13-35.

Brad, L. Dobre, F., Ciobanu, R., dan Brasoveanu, I. V. 2015. The interaction between financial audit and corporate governance: evidence from Romania. Procedia Economics and Finance, Vol. 32: 27-34.

Byrd, J. W., dan Hickman, K. A. 1992. Do outside directors monitor managers? Evidence from tender offer bids. Journal of Financial Economics, Vol. 32:195-221.

Cheng, P., Chen, J. J., dan Xiao, X. 2015. Expropriation, weak corporate governance and Post-IPO Performance: Chinese Evidence. Issues in Corporate Governance and Finance, Vol. 12: 237-267.

Cheng, Q., dan Warfield, T. D. 2005. Equity incentives and earnings management. The Accounting Review, Vol. 80 (2): 441-476.

Klein, A. 2002. Audit committee, board of director characteristics, and earnings management. Journal of Accounting and Economics, Vol. 33: 375-400.

Lizinska, J., dan Czapiewski, L. 2018. Earnings management and the Long-Term market performance of Initial Public Offerings in Poland. Finance and Sustainability: 121-134.

Lorca, C., Sanchez-Ballesta, J. P., dan Garcia-Meca, E. 2011. Board effectiveness and cost of debt. Journal of Business Ethics, Vol. 100: 613-631.

Mohammad, W., Wasiuzzaman, S., dan Nik Salleh, N. M. Z. 2016. Board and audit committee effectiveness, ethnic diversification and earnings management: a 
study of the Malaysian manufacturing sector. Corporate Governance: The International Journal of Business in Society, Vol. 16 (4): 726-746.

Park, Y. W., dan Shin, H. 2004. Board composition and earnings management in Canada. Journal of Corporate Finance, Vol. 10: 431-457.

Xie, B., Davidson, W. N., dan DaDalt, P. J. 2003. Earnings management and corporate governance: the role of the board and the audit committee. Journal of Corporate Finance, Vol. 9: 295-316. 